\title{
The International Relations of the Hashemite Kingdom of Jordan: Circumstances and Obstacles
}

\author{
Wesam Daghestani ${ }^{1, *}$ Ramzi Ansari $^{1, \mathrm{a}}$ Somar Ghanem ${ }^{1, \mathrm{~b}}$ \\ ${ }^{1}$ Peoples' Friendship Universit of Russia, Moscow, Russia \\ ${ }^{a}$ Email: somarghanem@gmail.com \\ ${ }^{b}$ Email: ramzi-lolo@hotamil.com \\ *Corresponding author. Email: wisam_s_d@yahoo.com
}

\begin{abstract}
This paper is devoted to explain the current situation of the International Relations of the Hashemite Kingdom of Jordan and put its foreign policy under the microscope. The international relations of Jordan constitute one of the geostrategic influences of the Kingdom in its surroundings. In view of the growing political, economic, security and military changes in the international system and its policies towards the Arab region, Jordan's foreign policy and Jordan's vital interests have been affected. Jordan faces many difficult choices in the method and methodology of dealing with these transformations and obstacles, which are affecting Jordan's role, strategy, interests, stability, and external relations. This article also discusses the main obstacles that Jordan is facing nowadays, and also gives some bits of advice for the decision makers to make more reasonable decisions.
\end{abstract}

Keywords: International relations strategy, Geopolitical factor, Strategic relations map, Regional studies, Middle Eastern regional subsystem.

\section{INTRODUCTION: AN OVERVIEW OF JORDAN'S STRATEGIC RELATIONS}

In view of the reality of its international relations, Jordan plays an important role and is at the center of the regional concern, especially with regard to security and politics. In light of this, Jordan's international relations map has been formed, where it has "alliance" relations with the United States, as well as with the European Union and Britain. [1]

Jordan has balanced relations with China, Russia, and Japan, as well as with many other countries in Asia, Africa, and South America, but it does not live up to its relations with major industrial powers.

The most important problem of this map in international relations is that Western policies generally adopt Israeli policies that directly affect the stability, role, and future of the Kingdom. They also constitute a burden on the Jordanian economy by virtue of the IMF's policies and policies, Security and counter-terrorism.[2]
In contrast, Jordanian relations with the United States, Europe in general and Britain, in particular, have formed an international protection umbrella for the Kingdom from Israeli ambitions in the medium term. It has also been an important source of economic and military support in many stations, as well as technical and other security support, the growing political differences with the United States, especially with regard to the "Century Deal", may create a number of new challenges to these relations, which may affect Jordan in the relevant areas. [3]

However, Jordan's attempts to diversify its international relations, including military and economic options, especially with Russia and China, are an attempt to gain the trust of these countries and ensure their support to any actions that Jordan is entitled to make when it comes to dealing with the regional issues. And that explains the high level of coordination between Russia and China from one side and Jordan from the other side regarding the Syrian Crisis according to the statement of His Majesty King Abdulla II during the visit to China 5 years ago.[4] 
In general, the reality of the Kingdom's international relations continues to serve its supreme national interests as an important criterion and variable in the approach of the Kingdom's external relations, and it has an important regional and international role in the region.

Palestine is located in the western part of the Hashemite Kingdom of Jordan. The West Bank of the Jordan River was geographically under the Jordanian guardianship until it was occupied by the Israelis in 1967. But the West Bank residents remained linked to a civilian under Jordanian guardianship until Jordan decided to disengage the Palestinian population from the West Bank in 1988. The Islamic sanctities in Jerusalem remained under Jordanian Hashemite custody until this time.[5]

The Kingdom has recognized the PLO as the sole legitimate representative of the Palestinian people. Permanent Jordanian passports given to Palestinians within the West Bank have been replaced by temporary passports. The Palestinians in Jordan have permanent Jordanian passports guaranteeing full citizenship rights within Jordan. The Foreign Policy of the Hashemite Kingdom of Jordan towards the Arab-Israeli Conflict: The Jordanian policy towards the Palestinian-Israeli conflict was to support the political situation of the PLO in Arab and international forums. After the signing of the Palestinian-Israeli agreement in Oslo, Israeli-Jordanian negotiations ended with the signing of a peace agreement between Jordan and Israel. As a result of Israeli intransigence and continued political support for the Palestinians.[6]

Jordan is paying a heavy price for its support for the Palestinian position, which rejects the American deal, because of its adherence to Jordanian guardianship and the protection of Islamic holy sites in Jerusalem. It is under economic and political pressure to change its position.

The Kingdom maintains its firm position in support of the Palestinian position while at the same time trying to maintain the support of the Arab countries that support the deal of the century and good relations with the United States of America, taking advantage of the geopolitical position of the Kingdom with Israel and Palestine.

Jordan has not responded to attempts to engage in military actions outside the border with Western and regional pressure while cooperating in the fields of intelligence and logistics with these practices and pay some of the transit costs in return.

\section{PREDICTIONS OF JORDAN'S INTERNATIONAL RELATIONS}

Given the strategic importance of Jordan's international relations, considering possible transition scenarios in the coming years is a reflection of how to deal with the difficult choices facing the Kingdom locally, regionally and internationally.

The Kingdom's international relations are expected to witness the following possibilities:

- 1-A decline in Jordan's relations with the United States because of the transfer of its embassy to Jerusalem and start marketing the deal of the century, which is believed to be at the expense of Jordan and taking into account his interests.

- 2-This may be in line with Jordan's continued international relations with the European Union and Britain to maintain its "alliance" with the Western system in the region by describing Europe's complementary policies and assistance.

- 3-The relations between Jordan, China, and Russia are expected to witness economic progress with the former, military and security, and the second by the current developments in the region and Jordan's pivotal role in security in the Arab regional subsystem, especially in Syria and Iraq.

- 4-At the international level, it is expected that the Jordanian-Indian and Asian relations will witness some progress while remaining at an average rate with African and Latin American countries. [7]

\section{OBSTACLES}

The changes taking place in the world and the region have in part imposed more convergence with Western policies, with some limited contradictions or some temporary defiance, such as during the American war on Iraq, where the port of Aqaba was blocked and economic aid halted in 1991, The Israeli occupation of Jerusalem and its violations of Palestinian human rights, and finally in the declaration of the United States Jerusalem as the capital of Israel contrary to the position and international law and rules of Jordanian-American relations, which may increase the gap in the case if the United States went in the crystal Its project to settle the Palestinian issue away from the interests of Jordan and its role and vision of peace in the region. [8] 
However, such transformations are not expected to push Jordan, for example, to choose new international alliances that are contrary to or contrary to Western policies, whether with China, Russia or some African and Asian countries, which makes the transformations have a temporary and limited effect. [9]

The international and Jordanian sides have to keep at least the minimum level in activating relations and do not think of fundamental changes in the various fields. Both the US Vice President and the Foreign Minister visited Jordan with the aid, although Jordan took a high position against the decision of the administration But also moved the Arab and Islamic groups along with the Palestinian side, especially in the UN vote against the resolution. [10]

\section{RECOMMENDATIONS}

Three paths can be envisaged to achieve the geostrategic situation that is more secure and stable for Jordan, supported by economic stability:

- To maintain Jordan's international relations with the West in the foreseeable future, to achieve economic support and provide political umbrella and military and security support, even in the face of differences on positions on the Palestinian issue, taking into account that the West cannot do without Jordan and Jordan needs the West.

- The expansion of Jordan's regional and international non-Western and Israeli relations to provide viable alternatives in the economic, military and security fields in the event of growing and exacerbating differences with the West or with Israel in the longer term, especially with China, Russia and the rest of the Brix countries, as well as Turkey and Iran.

This choice in the strategic thinking of the Kingdom's international relations makes it more capable of maneuvering, countering transformations and protecting economic, political and security stability, and gives greater independence to the political decision based on the supreme interests of the Kingdom and the Arab nation and the Palestinian cause.

- To consider the internal policies of the Kingdom and strengthen the internal front through comprehensive reforms as a basic entry point to strengthen Jordan's foreign policy and enhance its options in dealing with the changes and challenges it faces and to strengthen its ability to withstand any pressures not commensurate with its interests and the Palestinian cause.

\section{CONCLUSION}

Jordan has a very complicated situation, the crisis in Syria and Iraq, as well as refugees flow from both countries, the unrest in Lebanon, Palestine and the relation with Israel.

But the number one concern which must be for the kingdom of Jordan is the relations with Saudi Arabia and UAE. Because these two countries are building good relations with Israel which in turn is having difficulties to reach out to Jordan. Donald Trump's administration led by Jarred Kushner and the enormous efforts to bring these relations with Israel is having a huge impact on Jordan, however Jordan's support to the Palestinian case is not going to end.

We have also seen a Jordanian support to the Russian great role in Syria, the high level of cooperation on both military and info-intelligence between Jordan and Russia is also going to negatively affect the relations between Jordan and Trump's administration.

Therefore, Jordan is going to seek more regional supporters (allies) expectedly with Egypt or Iraq. Also, the previously mentioned issues are going to bring Jordan to Russia closer, as well as Turkey.

\section{AUTHORS' CONTRIBUTIONS}

Wesameddin Aldaghestani (Jordan): compiled and analysed the Jordanian foreign policy by compiling the documents from the ministry of foreign affairs and published articles.

Somar Ghanem (Syria): Analysed the Jordanian role in the Crisis of Syria and identified the main obstacles and challenges that are facing Jordan in this particular area.

Ramzi Ansari (Palestine): has analysed the Jordanian interaction with the regional powers, and identified the main key priorities of Jordan.

\section{REFERENCES}

[1] Ministry of Foreign Affairs of Jordan: "the national strategic plan". See it on May 12, 2011. 
[2] Anne E. Kornblut: “Obama, Mubarak Discuss Mideast Peace" The Washington Post. August 182009

[3] RHC Royal Hashemite Court 2014 website : https://youtu.be/iCLuP633o_Q

[4] RT news Arabic: "Jordan - Russian negotiations to solve the Syrian refugees problem" Feb 3, 2019

[5] Indian Government - Ministry of foreign affairs: " list of all the agreements signed during the visit of King Abdulla of Jordan" March 1st, 2018

[6] BBC news - Jordan Country profile $22 \mathrm{Feb}$ 2019

[7] Aljazeera news: "Jordan MPs demand expulsion of Israeli envoy over Al-Aqsa dispute" 20 feb 2019

[8] Al - Hawar Urban Magazine - Yaser QtaishatJordanian Foreign Policy- 21 -5 - 2011

[9] Al Ghad Channel - MOHAMED HIJAZI Arabs in the deal equation century - 25-62018

[10] PETRA NEWS - MOONES AL-RAZZAZ The deal of the century evaporates in front of the Jordanian constants. 